Bangladesh J. Bot. 38(1): 71-76, 2009 (June)

\title{
ENTEROBACTER STRAIN 9410-O WITH POROUS SUBSTRATES TO ENHANCE HETEROTROPHIC ACTIVITY IN BOTTOM WATER ENVIRONMENT
}

\author{
Md. Abdul Karim ${ }^{1}$ and Kimio Fukami \\ Laboratory of Aquatic Environmental Science, Faculty of Agriculture, Kochi University, \\ Otsu 200 Monobe, Nankoku, Kochi 783-8502, Japan
}

Key words: Enterobacter, Bottom environment, Porous substrates, Nitrogen, Phosphorus

\begin{abstract}
Mesophilic Enterobacter strain 9410-O isolated from a eutrophic bottom water environment and introduced into it to enhance heterotrophic activities and decompose organic matters in situ. The bacteria were added as cell suspension after absorbing with porous substrates, like Eco-breath, Neo-coal and Accela35. The strain stimulated net regeneration of dissolved inorganic nitrogen and inorganic phosphorus from the sediment by approximately three to fourfolds at 21 and $23^{\circ} \mathrm{C}$, respectively. It appears that the application of Enterobacter strain 9410-O with Neo-coal as substrate would be promising for the purification of eutrophic bottom water environment.
\end{abstract}

\section{Introduction}

Uranouchi Inlet, Kochi prefecture, Japan is highly eutrophic due to anonymous practices of fish cage culture with high protein nutrient input, mainly in the form of high protein content in fish feed. A small portion of total fish feed input is recovered by the cultivated fish but a large portion remain either dissolved into the recipient water or settle down onto the sediment (Hans and Enell 1990, Kupka-Hansen et al. 1991, Hall et al. 1992 and Johnsen et al. 1993). Furthermore, inlet is characterized by limited water exchange and pronounced density stratification in summer with oxygen-rich surface and oxygen-deficient bottom environment. These imply heterotrophic activities at the study site are limited by dissolved oxygen (DO) concentration in summer, especially in bottom environment. For improving organic rich bottom environments by stimulating heterotrophic activities, it was envisaged that addition of some promising bacteria possessing higher metabolic activities in a specific limiting environmental situation might accelerate the decomposition rate in situ.

The objectives of the present work were, (i) selection of effective indigenous mesophilic bacterial strain, (ii) selection of an useful substrate to carry bacterial cells into the sedimentbottom water complex system, and (iii) enhancement of heterotrophic activity in the system.

\section{Materials and Methods}

Study site and sampling: Mitsumatsu sampling and study station in Japan is a eutrophic area of the Uranouchi Inlet practicing intensive fish farming in cages (Fukami et al. 1991b, Karim et al. 2003). The average depth near the sampling point was 17-18 meter. Water samples were collected from bottom (16 m depth) environment and sediment samples were collected from $0-1 \mathrm{~cm}$ deep surface sediment.

Isolation and selection of bacteria: One hundred and ten bacterial strains were isolated from the sediment of the study site in October, 2000. Considering growth pattern and colony morphology 20 bacterial strains were primarily selected for further study.

${ }^{1}$ Corresponding author. Laboratory of Microbiology, Department of Botany, University of Dhaka, Dhaka1000, Bangladesh.<makarim10@yahoo.com>. 
The growth curves of Enterobacter strain 9410-O were prepared by direct-count method using DAPI (4', 6-diamidino-2-phenylindole dihydrochloride) stain (Porter and Feig 1980, Fukami et al. 1991a, Patel et al. 2002 and Karim et al. 2003). Bacterial cells growing in FeTY broth medium (Fukami et al. 1992) were conducted for 0, 6, 12, 18, 24, 36, 48, 60 and $72 \mathrm{hr}$ of incubation at $5,10,15,20,25$ and $30^{\circ} \mathrm{C}$.

Preparation of bacterial suspension: Bacterial culture was centrifuged at 10,000 rpm (Himac CR 21E, Hitachi) for 10 minutes at $10^{\circ} \mathrm{C}$. The supernatant was discarded and bacterial pellet was gently rinsed with filter-sterilized $(0.22 \mu \mathrm{m})$ bottom water at least five times in order to remove associated nutrients and re-suspended with filtered bottom water by pipetting. Three $\mathrm{ml}$ of bacterial cell re-suspension was used as inocula. Five $\mathrm{ml}$ was fixed with pre-filtered $(0.22 \mu \mathrm{m})$ formalin (final concentration 2\%, v/v) for counting the density of added bacterial cells by directcount method using DAPI stain (Fukami et al. 1992).

Porous substrates and incubation: Three porous substrates like, Eco-breath, Neo-coal and Accela-35 (Eastluck International Ltd., Kochi, Japan) were selected, characteristics of which are shown in Table 1. During experiments with porous substrates, $10 \mathrm{~g}$ substrate was taken and after absorbing bacterial cells, each substrate was introduced into one liter glass bottle. In the control bottle same amount of porous substrate was used.

Table 1. Characteristics of three porous substrates used in the experiment.

\begin{tabular}{|c|c|c|c|c|c|c|c|}
\hline Substrates & Color & Composition & $\begin{array}{l}\text { Absorbing capacity } \\
(\mathrm{ml} \text { suspension } / 100 \mathrm{~g})\end{array}$ & $\begin{array}{l}\text { Diameter } \\
(\mathrm{mm})\end{array}$ & $\begin{array}{l}\text { Weight } \\
\text { (g) }\end{array}$ & Sp. gr. & $\begin{array}{l}\text { Pore } \\
\text { size } \\
(\mu \mathrm{m})\end{array}$ \\
\hline Eco-breath & Ash & $\begin{array}{l}\text { Ash of charcoal } \\
\text { and powder of } \\
\text { waste glass bottles }\end{array}$ & 17.5 & $\begin{array}{l}15 \\
\pm 4\end{array}$ & $\begin{array}{r}0.49 \\
\pm 0.30\end{array}$ & 2.0 & $5-7$ \\
\hline Neo-coal & Muddy & $\begin{array}{l}\text { Wood charcoal } \\
\text { and ceramic }\end{array}$ & 36.3 & $\begin{array}{l}13 \\
\pm 1\end{array}$ & $\begin{array}{r}0.27 \\
\pm 0.07\end{array}$ & 1.3 & $\begin{array}{l}20 \AA \& \\
5-15 \mu \mathrm{m}\end{array}$ \\
\hline Accela-35 & Brick & $\begin{array}{l}\text { Sand and fine } \\
\text { powder of clay, } \\
\text { including silt }\end{array}$ & 30.0 & $\begin{array}{l}14 \\
\pm 3\end{array}$ & $\begin{array}{r}0.33 \\
\pm 0.10\end{array}$ & 1.5 & $10-100$ \\
\hline
\end{tabular}

The glass bottles were incubated in a dark condition in situ (in duplicate) at $21^{\circ} \mathrm{C}$ temperature during May, 2002 and at $23^{\circ} \mathrm{C}$ during June, 2002 for 12 days without any shaking to estimate the heterotrophic activity. Dissolved oxygen concentration was monitored by YSI, Model No. 85/10 FT, at every sub-sampling occasion before taking sub-samples without shaking.

Sub-sampling and nutrient analysis: Just after adding bacteria $25 \mathrm{ml}$ sub-samples were taken at the beginning of the incubation as 0 -day. At 2 days interval $25 \mathrm{ml}$ sub-samples were pipetted aseptically from $2 \mathrm{~cm}$ above the sediment surface of each bottle without any disturbance of the system and preserved at $-25^{\circ} \mathrm{C}$ temperature. Concentration of dissolved inorganic nitrogen (DIN) as ammonium, nitrate and nitrite and dissolved inorganic phosphorus (DIP) in the sub-samples were measured by using automatic analyzer (Bran + Luebbe TRAACS 800).

\section{Results and Discussion}

Enterobacter strain 9410-O exhibited remarkably high growth rate between 20 and $30^{\circ} \mathrm{C}$ but did not grow well at relatively low temperatures $\left(\leq 7^{\circ} \mathrm{C}\right)$ (Fig. 1). Regarding protein hydrolyzing capacity, the diameter of the clear zone after $24 \mathrm{hr}$ and at the end of the incubation were larger with increasing incubation temperatures (Karim et al. 2003). 


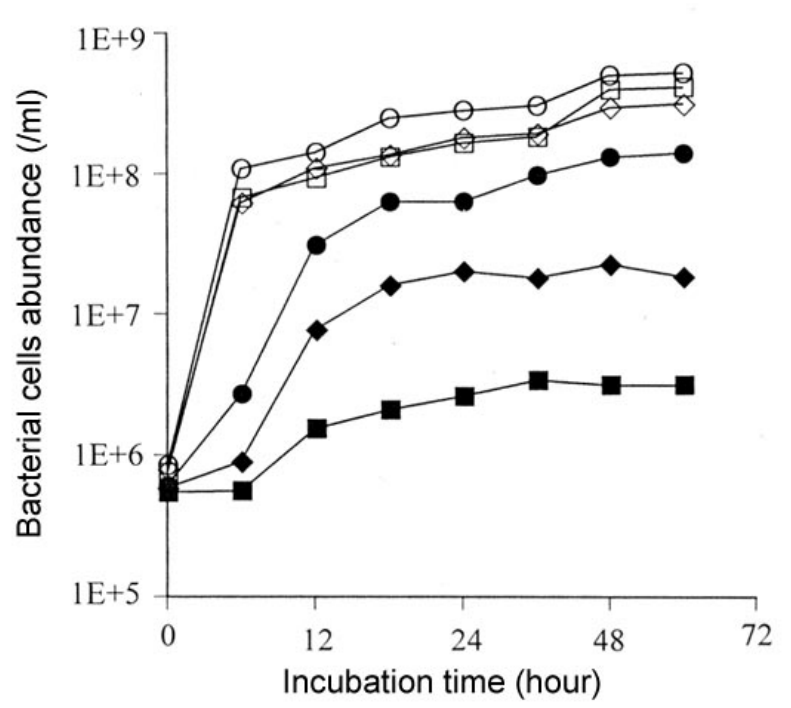

Fig.1. Growth curve of Enterobacter strain 9410-O in FeTY broth medium at different temperatures between 5 and $30^{\circ} \mathrm{C} .5^{\circ} \mathrm{C}(--), 10^{\circ} \mathrm{C}(-\bullet-), 15^{\circ} \mathrm{C}(-\bullet-), 20^{\circ} \mathrm{C}(-\square-), 25^{\circ} \mathrm{C}(-\diamond-)$ and $30^{\circ} \mathrm{C}(-\mathrm{O}-)$.

Effects of substrates on heterotrophic activity: Effects of Eco-breath, Neo-coal and Accela-35 on the net release of DIN and DIP for 12 days after adding bacteria are shown in Fig. 2. Use of Eco-breath released $39.4 \mu \mathrm{M}$ DIN and $2.38 \mu \mathrm{M}$ DIP, while those without adding bacteria released $34.8 \mu \mathrm{M}$ DIN and $2.19 \mu \mathrm{M}$ DIP (Fig. 2, upper). When bacteria were added after absorbing onto Neo-coal, DIN and DIP were $36.2 \mu \mathrm{M}$ and $0.78 \mu \mathrm{M}$, respectively. With the addition of bacteria it increased to $55.3 \mu \mathrm{M}$ DIN and $2.00 \mu \mathrm{M}$ DIP, over the control (Fig. 2, middle). Furthermore, when Accela-35 was used net release of DIN and DIP without adding bacteria were 32.0 and $2.10 \mu \mathrm{M}$, respectively but increased to $44.7 \mu \mathrm{M}$ DIN and $2.15 \mu \mathrm{M}$ DIP, respectively after adding bacteria (Fig. 2, bottom). Comparison of the net release of DIN and DIP due to different substrates showed that Neo-coal is the best (Fig. 2). The DO concentration was reduced during 12 days incubation period when bacteria were added with three substrates (Table 2).

Table 2. Effect of Enterobacter strain 9410-O on dissolved oxygen concentration (mg/l) at $20^{\circ} \mathrm{C}$ when incubated with the three substrates.

\begin{tabular}{|c|c|c|c|c|c|c|}
\hline \multirow{2}{*}{ Treatments } & \multicolumn{2}{|c|}{ Eco-breath } & \multicolumn{2}{|c|}{ Neo-coal } & \multicolumn{2}{|c|}{ Accela-35 } \\
\hline & Initial & Final & Initial & Final & Initial & Final \\
\hline Without Enterobacter sp. & 3.85 & 1.50 & 3.48 & 1.28 & 3.43 & 1.37 \\
\hline With Enterobacter strain 9410-O & 3.76 & 1.34 & 3.46 & 1.19 & 3.38 & 1.15 \\
\hline
\end{tabular}

Net release of DIN and DIP: Due to incubation with bacteria in situ at $21^{\circ} \mathrm{C}$, concentration of DIN and DIP released into the overlying water increased (Fig. 3A, B). The net releases of DIN and DIP from sediment to water in a control were 69.04 and $1.70 \mu \mathrm{M}$, respectively, while in the system of adding bacteria, they increased 164.25 and $12.53 \mu \mathrm{M}$, respectively (Fig. 3A, B).

In an experiment, $10 \mathrm{ml}$ of killed bacterial cells re-suspension was added in control bottles as that of live cells re-suspension $(10 \mathrm{ml})$ in the treatment bottles with samples collected on June 21, 2002. At $23^{\circ} \mathrm{C}$, the net DIN concentration increased from 92.79 to $231.15 \mu \mathrm{M}$ with control 
counterparts, while after adding live cells it changed from 96.02 to $290.44 \mu \mathrm{M}$ during incubation period of 10 days (Fig. 3C, D). Accordingly, DIP concentration also increased from 2.64 to 18.42 $\mu \mathrm{M}$ in control (killed bacterial cells) and it changed from 2.83 to $23.32 \mu \mathrm{M}$ in treatments with live bacterial cells (Fig. 3C, D).

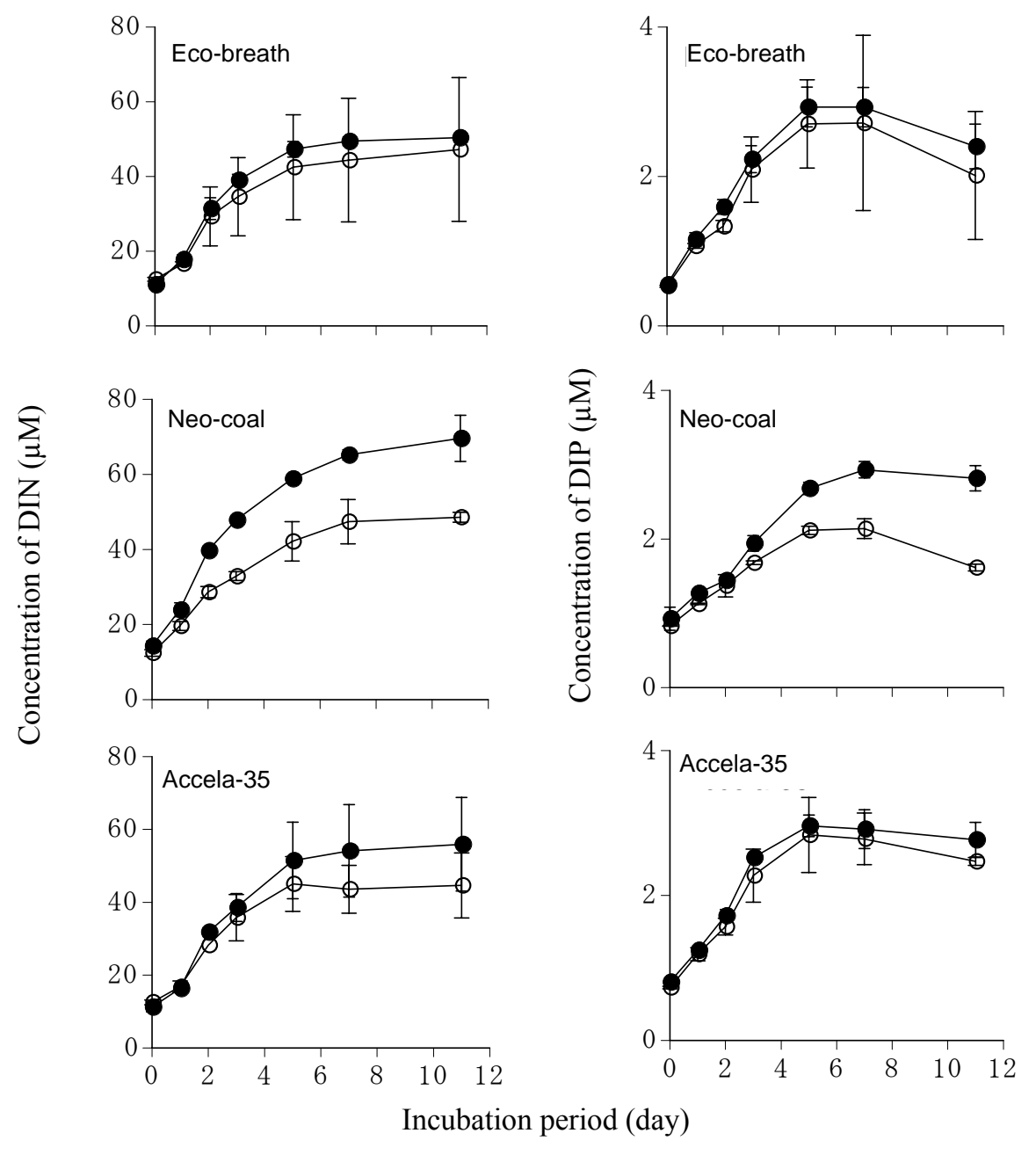

Fig. 2. Changes in concentration of DIN and DIP after adding Enterobacter strain 9410-O absorbed onto substrates Eco-breath, Neo-coal and Accela-35. Incubation temperature was $20^{\circ} \mathrm{C}$; sampling on May 09 , 2001. Without Enterobacter sp. (-O-) and with Enterobacter strain 9410-O (- • -). Bars = standard deviation; $\mathrm{n}=2$.

The accumulation of organic matter is one of the most common water quality problems in intensive fish culture systems (Muir 1982). The major pathway of utilization of organic nutrients by primary producers/phytoplankton in nature is through bacterial or free enzymatic breakdown to easily exploitable inorganic components such as $\mathrm{NH}_{4}^{+}$and DIP (Berman et al. 1999). Such 
strategies may help in alleviating the accumulation of organic matters, which in turn will contain the eutrophication (Cole 1993).

Master and Mohn (1998) have demonstrated that the growth of particular microorganisms could facilitate biodegradation of organic wastes even in large volumes of water. Net release of DIN and DIP after adding Enterobacter strain $9410-\mathrm{O}$ by absorbing onto substrate Neo-coal were fourfolds higher than those adding with Eco-breath (Fig. 2). The same trend was noticed when Neo-coal and Accela-35 substrates were used. Further study is needed to find the nature and type of interactions between added and ambient bacterial populations in the sediment bottom-water complex system.



Fig. 3. Changes in concentration of inorganic nutrients by adding Enterobacter strain 9410-O. A \& B. Incubation temperature was $21^{\circ} \mathrm{C}$; sampling on May 10, 2002. Without Enterobacter sp. (-o-) and with Enterobacter strain 9410-O (- •-). C \& D. Incubation temperature was $23^{\circ} \mathrm{C}$; sampling on June 21, 2002. With killed cells (-O-) and with live cells $(-\bullet-)$. Bars $=$ standard deviation; $\mathrm{n}=2$.

\section{Acknowledgements}

The authors are grateful to Professor Dr. T. Nishijima and Dr. M. Adachi for their valuable suggestions and help related to the study. Students of the laboratory of Aquatic Environmental Science (LAQUES) and the staff of the Marine Biological Research Center, Usa (Japan) helped during sampling and/or chemical or biological analysis for which the authors are thankful. The authors gratefully acknowledge the support in part by a Grant-in-aid (Bio Renaissance Program) from the Ministry of Agriculture, Forestry and Fisheries (Japan) (BRP-98-II-B-1). 


\section{References}

Berman, T., C. Béchemin and S.Y. Maestrini. 1999. Release of ammonium and urea from dissolved organic nitrogen in aquatic ecosystems. Aquat. Microb. Ecol. 16: 295-302.

Cole, J. 1993. Controlling environmental nitrogen through microbial metabolism. Tibtech. 11: 368-372.

Fukami, K., B. Meier and J. Overbeck. 1991a. Vertical and temporal changes in bacterial production and its consumption by heterotrophic nanoflagellates in a north German eutrophic lake. Arch. Hydrobiol. 122: 129-145.

Fukami, K., T. Nishijima, H. Murata, S, Doi and Y, Hata. 1991b. Distribution of bacteria influencial on the development and the decay of Gymnodinium nsgasakiense red tide and their effects on algal growth. Nippon Suisan Gakkaishi 57: 2321-2328.

Fukami, K., T. Nishijima and Y. Hata. 1992. Availability of deep seawater and effects of bacteria isolated from deep-sea water on the mass culture of food microflora Chaetoceros ceratosporum. Nippon Suisan Gakkashi 58: 931-936.

Hall, P.O.J., O. Holby, S. Kollberg and M. Samuelsson. 1992. Chemical fluxes and mass balances in a marine fish cage farm. IV. Nitrogen. Mar. Ecol. Prog. Ser. 89: 81-91.

Hans, A. and M. Enell. 1990. Discharges of nutrients from Swedish fish farming to adjacent sea areas. Ambio. 19: 28-35.

Johnsen, R.I., O. Grahl-Nielsen and B.T. Lunestad. 1993. Environmental distribution of organic waste from a marine fish farm. Aquaculture 118: 229-244.

Karim, M.A., K. Fukami and A.B. Patel. 2003. Enhancement of inorganic nutrient regeneration in a eutrophic sediment-bottom water complex system by adding effective indigenous bacteria. Fisheries Sci. 69: 1146-1157.

Kupka-Hansen, P., K. Pittman and A. Ervik. 1991. Organic waste from marine fish farms: Effects on the seabed. In: Marine aquaculture and environment. Makinen T. (Ed). Nord. 22: 105-119.

Master, E.R. and W.W. Mohn. 1998. Psychrotolerant bacteria isolated from Arctic soil that degrade polychlorinated biphenylls at low temperatures. Appl. Environ. Microbiol. 64: 4823-4829.

Muir, J.F. 1982. Recirculated water systems in aquaculture. In: Recent advances in aquaculture. J.F. Muir and R.J. Roberts (Eds.). pp. 357-447. Westview Press, Boulder, Colorado.

Patel, A.B., K. Fukami, A. Karim and T. Nishijima. 2002. Stimulation of regeneration of inorganic nitrogen and phosphorus in surface and bottom waters of a eutrophic inlet by adding effective bacteria. Microb. Environ. 17: 205-213.

Porter, K.G. and Y.S. Feig. 1980. The use of DAPI for identifying and counting aquatic microflora. Limnol. Oceanogr. 25: 943-948.

(Manuscript received on 9 March, 2009; revised on 23 May, 2009) 